\title{
The Effect of Company Characteristics on Tax Avoidance and Its Impact on Firm Value
}

\author{
N. Heriyah* \\ Faculty Economic and Business, Universitas Informatika dan Bisnis Indonesia, Bandung, Indonesia \\ *Corresponding author. Email:heryahamoy@gmail.com
}

\begin{abstract}
There are two ways companies can pay taxes more effectively, namely by reducing the value of the tax by adhering to the applicable taxation regulations, said to be reducing the value of taxes by taking actions that are not in accordance with the Taxation Law or tax evasion. This study was conducted to examine the effect of company characteristics on firm value where tax avoidance is an intervening variable or a mediating factor. Sampling using purposive sampling method. The research sample consisted of 18 manufacturing companies listed on the Indonesia Stock Exchange for the period 2015 until 2018. The hypothesis was tested using partial least square software. Results showed that the company characteristics, namely profitability, had positive effect on tax avoidance. Meanwhile, leverage and firm size do not have positive effect on tax avoidance. Profitability and firm size have a positive effect on firm value. Leverage does not have positive effect on firm value. Results also show that tax avoidance has positive effect on firm value, but tax avoidance is not able to mediate the effect of profitability and leverage on firm value. Avoidance is able to provide a mediation of firm size on firm value.
\end{abstract}

Keywords: Company Characteristics, Tax Avoidance, Firm Value

\section{INTRODUCTION}

The concept of state development cannot be separated from the tax sector. Taxes are the largest source of state revenue that can be used, such as infrastructure development, improving education, strengthening state resilience and security, and regional development. One of the hopes of the Directorate General of Taxes (DGT) in terms of tax revenue is from the manufacturing industry sector [1]. Based on data obtained from the Central Government Financial Statements (LKPP) from 2015 to 2018 , the realization of tax revenues has still not reached the target, where the realization of tax revenues respectively reached $83.29 \%, 83.48 \%, 91.23 \%, 93.86 \%$. Indonesia's tax ratio is in the range of $11 \%$ which puts Indonesia in the ranks of the world's low tax ratios. This ratio places Indonesia far behind in the ranks of middleclass countries, namely $14 \%-15 \%$ and developed countries reaching $24 \%-26 \%$.

Tax regulations for multinational companies are no longer compatible with the rapidly changing global business between countries, increasingly complex corporate structures, ease of business mobility, and legal differences between countries. Many multi-national companies are implementing Base Erotion and Profit Shifting (BEPS) to reduce or avoid their tax obligations to the state. BEPS refers to tax avoidance strategies by utilizing gaps or loopholes contained in taxation legislation (domestic) and differences in taxation systems between countries. Tax avoidance can be done by exploiting loopholes in tax regulations while still not violating applicable laws. Tax Avoidance can be effect by several factors including profitability, leverage, company size and will also have an impact on company value.

The decline in the tax ratio can be seen from 2014 until it increased again in 2017. The increase and decrease in the tax ratio is the impact of the strength or weakness of the existing tax system in a country. One of the reasons for the decline in the tax ratio was due to the many cases of tax avoidance, especially in the manufacturing sector.

Taxes for companies are a burden that will reduce net income so that companies always want to pay as little tax as possible [2]. The existence of a tax burden that burdens the company and its owners, so there are efforts to avoid taxes [3]. Companies take advantage of unclear regulations in the context of delivering taxes to obtain favorable tax outcomes [4]. Tax avoidance is an explicit tax rate reduction that represents a series of tax planning strategies 
starting from tax management, tax planning, tax aggressive, tax evasion, and tax sheltering [5].

Based on the phenomenon that occurs in tax avoidance, especially in manufacturing industrial companies, this research is aimed to analyze the effect of company characteristics on firm value where tax avoidance is an intervening variable or a mediating factor.

\section{THEORETICAL}

\subsection{Profitability}

The profitability is the net result of a large number of policies and decisions. The ratio examined thus far reveals some interesting thing about the wry the firm operates, but the profitability ratio shows the combined objects of liquidity, asset management, and debt management on operating melt [6]. The profitability of the firm is one of the basic assessments of the firm's condition.

Frank and Goyal (2003) stated in the Pecking Order theory that profitable firm will better able to paying dividends, paying debt, and having cash [7].

The profitability ratio has benefits not only for business owners or management, but also for external parties, especially those who have a relationship or interest with the company [8].

Profitability ratio is a ratio that measures the success or operation of a company for a certain period of time [9]. Profitability can be seen in the signaling theory which discusses the ups and downs of market prices such as stock prices and bonds so that it will influence investors' decisions. Market conditions are strongly influenced by investor responses, be it positive signals or negative signals. The market will strongly react in various ways in response to these signals The existence of profitability growth shows that the company's prospects are getting better because of the potential for increased profits to be obtained by the company. This research, the measuring tool that will be used Return On Equity.

\subsection{Leverage}

The firm's financing sources can be in terms of short-term financing or long term that will cause an effect known as leverage. Firm's leverage can be used to increase the level of expected profit [10].

The definition of Leverage is the ability of companies to use assets or funds that have fixed costs (fixed cost assets or funds) to increase the level of income (return) for company owners [11].

Debt to Equity Ratio (DER) is a ratio that shows the ratio between total debt and equity. This result shows the relationship between total liabilities and the amount of equity provided by the company owner [12]. Debt to
Equity Ratio (DER) is a ratio that shows the ratio between total debt and equity. These results indicate the relationship between total liabilities and the amount of own capital provided by the company owner [12]. This ratio is mean the level of debt to capital owned by the company. Debt to equity ratio can reflect a company's ability to pay its debts with capital (the capital it owns). This ratio is also able to assess the company's ability to use capital from loans to support company activities, especially to increase company profits. Therefore, companies prefer to cover their debts rather than distribute dividends.

\subsection{Firm Size}

Firm size is a measure of the value of equity, total sales, or total value of assets owned by the firm. state that large firms will tend to diversify more than small firms [13]. Therefore, the possibility of failure or bankruptcy of large firm will be smaller. According to signalling theory, larger firm size will give positive signals to investors, so it increases the firm's value. So, investor and lender strongly believe in the firm, and they will easily provide funding. However, the larger the firm size, the larger the possibility of occurrence of agency problems.

Firm size is a measure of the value of equity, total sales, or total value of assets owned by the firm. state that large firms will tend to diversify more than small firms [13]. Therefore, the possibility of failure or bankruptcy of large firm will be smaller. According to signaling theory, larger firm size will give positive signals to investors, so it increases the firm's value. So, investor and lender strongly believe in the firm, and they will easily provide funding. However, the larger the firm size, the larger the possibility of occurrence of agency problems.

The size of the company is very dependent on the size of a company which also affects the capital structure and is closely related to the company's ability to obtain loans. Large companies are considered easier to obtain loans because the asset value pledged as collateral is greater and the level of bank confidence is higher when compared to small companies

\subsection{Agency Theory}

This theory explains the relationship between parties who delegate decision making or owners or shareholders and the party receiving the delegation in the form of a Cooperation contract. In this cooperation, the owner delegates to the manager as an agent to manage resources efficiently to get maximum profit. An agency relationship arises from an engagement between two or more people. The manager is in charge of making decisions and representing the interests of those who designate the so- 
called owners with other parties who are generally associated with solving a problem [14].

\subsection{Tax Avoidance}

Dyreng et al. (2010) define tax avoidance as follows: "Tax avoidance is any form of activity that gives effect to the tax obligation, whether activities are allowed by tax or special activities that reduce taxes [4]. Tax avoidance is usually done by exploiting the weaknesses of the tax law and not violate the law "

In this study the authors used the CETR formula, which aims to indicate tax on the company. CETR describes all tax avoidance activities that reduce tax payments to tax authorities and CETR is not affected by changes in estimates such as provision for valuation or tax protection.

\subsection{Firm Value}

Firm value remained relevant to most researchers for the past decades. This is because diversified company considers as a significant player in an emerging market [15]. Most of the study determines what factors can affect the firm value. It was stated that firm's wealth, technology, organization structure, human resources with discounted future cash flows and environmental factors of industrial establishments can affect firm value. Another study uses customer satisfaction, management understanding, technology usage, and product quality as factors that influence firm value. There are also many studies that have identified firms' competitiveness as a factor that can affect firm value [16]

Firm value is the price a prospective buyer is willing to pay if the company is sold. The value of the company is often associated with the share price. The higher the stock price, the higher the company value [17].

The company is not only responsible to shareholders, but shifts to the social community and is hereinafter referred to as social responsibility.

\subsection{Framework}

In this study, it shows the effect of company characteristics as an independent variable, namely profitability, leverage, company size, on tax avoidance as an intervening variable and its impact on firm value as the dependent variable as follows:

Based on the theoretical framework above, profitability can be seen that the higher the ROE, the higher the profits so that they have a greater opportunity to do tax planning. This will indicate a high ROE value.
Leverage can be seen with a high DER value, where the higher the company's debt, the higher the interest expense. With this interest expense, it can reduce the company's tax burden.

Company size or firm size can be seen from the amount of assets owned by the company that can be used for company operations. The bigger the company, the greater the opportunity it has to take advantage of rules that can benefit the company. One of the ways to do this is by having human resources who are competent in their fields.

\section{METHODOLOGY}

\subsection{Population and Sample}

This research uses a population of 22 companies in the consumer and goods industry sector listed on the Indonesia Stock Exchange, using the company's annual data for the period 2015 to 2018. The population of industrial manufacturing companies is used because this type of company carries out complex activities so that in each business decision can have a considerable influence on various variables. Most of these relate to company characteristics, taxation, and company value, which can be seen from the positive growth in prices for the goods and consumption sector. Tax avoidance and firm value activities can be influenced by profitability, leverage, and company size. Besides that, manufacturing companies are expected to be able to represent all companies.

The sampling method was carried out by using purposive sampling method or purposive sampling, with the following criteria (See Table 1).

Table 1 Purposive Sampling Results

\begin{tabular}{lc}
\hline \multicolumn{1}{c}{ Sample Criteria } & Total \\
\hline The number of manufacturing companies in & 22 \\
the consumer and goods industry sector list on & \\
the IDX during period 2015-2018 \\
Sample Reduction : \\
Manufacture companies in the consumer and \\
goods industry sector that didn't publish \\
financial reports and auditors reports for the \\
financial years as of Dec 31 \\
Total Sample
\end{tabular}

The research sample used in this study includes 18 companies. 


\subsection{Research Model}

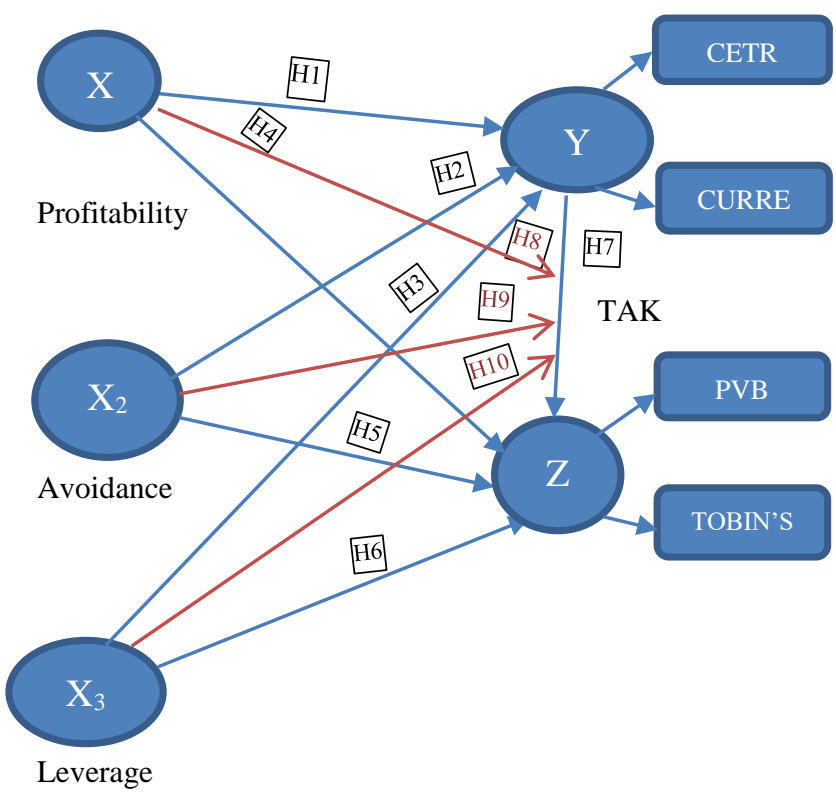

Figure 1 Research methods

For research method, can be seen in Figure 1.

\subsection{Data Collection Technique}

Data collection in this research was carried out through documentation study. To obtain answers to the research hypothesis, the data were processed using structural equation modeling software with partial least square (PLS) software interpretation.

In this research, profitability is measured by return on equity, leverage is measured by debt to equity ratio, company size is measured by the natural logarithm of total assets, tax avoidance is measured by cash effective tax rate, and firm value is measured by price to book value.

\section{RESULTS AND DISCUSSION}

\subsection{Validity test}

In Table 2, the results of the validity test show that the value of all indicators is greater than the kirteria 0.5 . This means that all indicators in dimensions and variables have good validity.
Table 2 Validity Test

\begin{tabular}{ccccc}
\hline Dimension & $\begin{array}{c}\text { Loadings } \\
\text { Factor }\end{array}$ & AVE & Criteria & Inf \\
\hline \multicolumn{5}{c}{ PROFITABILITY (X1) } \\
GPM & 0.75 & 0.639 & 0.500 & Valid \\
ROE & 0.867 & 0.500 & \\
\multicolumn{5}{c}{ LEVERAGE (X2) } \\
DER & 0.912 & 0.846 & 0.500 & Valid \\
LTDR & 0.934 & 0.500 & \\
\multicolumn{7}{c}{ SIZE (X3) } \\
MARKET & 0.667 & 0.735 & 0.500 & Valid \\
CAPTZN & \multicolumn{1}{c}{0.500} \\
SLS & 0.869 & \\
\multicolumn{7}{c}{ TAX AVOIDANCE (Y) } \\
CETR & 0.816 & 0.724 & 0.500 & Valid \\
CURRENT & 0.89 & 0.500 & \\
\multicolumn{5}{c}{ FIRM VALUE (Z) } \\
PBV & 0.989 & 0.734 & 0.500 & Valid \\
TOBINS'Q & 0.692 & 0.500 & \\
\hline
\end{tabular}

\subsection{Reliability Test}

Result show that the reliability test is above the 0.7 criterion for all variables. Thus, all profitability variables (X1), leverage (X2), Firm size (X3), tax avoidance (Y), and firm value $(\mathrm{Z})$ are consistent and can be trusted to be used in research. Result of Rehabilitee test can be seen in Table 3 .

Table 3 Rehabilitee Test

\begin{tabular}{lccc}
\hline Variable & $\begin{array}{c}\text { Cronbachs } \\
\text { Alpha }\end{array}$ & rho_A & $\begin{array}{c}\text { Composite } \\
\text { Reliability }\end{array}$ \\
\hline Pprofitability & 0.758 & 0.891 & 0.777 \\
Leverage & 0.820 & 0.853 & 0.918 \\
Size & 0.758 & 0.882 & 0.757 \\
Tax Avoidance & 0.731 & 0.836 & 0.840 \\
Firm Value & 0.758 & 3.551 & 0.842 \\
\hline
\end{tabular}




\subsection{Hypothesis Test}

Table 4 shows that all t-statistical values from indicator to variable are $>1.96$ and all $\mathrm{p}$-values from indicator to variable are $<0.05$. This means that all weight values and loading factors are relevant. On the other hand, there are three $\mathrm{t}$-statistics and $\mathrm{p}$-values from variable to variable that are not significant, namely the effect of leverage on tax avoidance, the effect of leverage on firm value and the effect of firm size on tax avoidance. By mediation, tax avoidance cannot mediate the relationship between profitability and leverage on firm value but can mediate the relationship between firm size and firm value.

Table 4 Hypothesis Test From Indicator to Variables

\begin{tabular}{|c|c|c|c|}
\hline GPM & 8.751 & 0.002 & Significant \\
\hline ROE & 22.084 & 0.000 & Significant \\
\hline DER & 15.351 & 0.000 & Significant \\
\hline MARKET CAPT & 3.824 & 0.016 & Significant \\
\hline Ln.PENJ & 1.773 & 0.017 & Significant \\
\hline CETR & 24.938 & 0.000 & Significant \\
\hline CURRENT & 21.320 & 0.000 & Significant \\
\hline PBV & 29.511 & 0.000 & Significant \\
\hline OBINS'Q Log & 3.048 & 0.028 & Significant \\
\hline \multicolumn{4}{|c|}{ From Variables to Variables } \\
\hline $\begin{array}{l}\text { Profitability -> Tax } \\
\text { Avoidance }\end{array}$ & 3.599 & 0.018 & Significant \\
\hline $\begin{array}{l}\text { Profitability -> Firm } \\
\text { Value }\end{array}$ & 3.197 & 0.025 & Significant \\
\hline $\begin{array}{l}\text { Leverage -> Tax } \\
\text { Avoidance }\end{array}$ & 0.249 & 0.409 & $\begin{array}{c}\text { Not } \\
\text { Significant }\end{array}$ \\
\hline $\begin{array}{l}\text { Leverage -> Firm } \\
\text { Value }\end{array}$ & 0.533 & 0.316 & $\begin{array}{c}\text { Not } \\
\text { Significant }\end{array}$ \\
\hline $\begin{array}{l}\text { Company Size -> Tax } \\
\text { Avoidance }\end{array}$ & 1.523 & 0.113 & $\begin{array}{l}\text { Not } \\
\text { Significant }\end{array}$ \\
\hline $\begin{array}{l}\text { Company Size -> Firm } \\
\text { Value }\end{array}$ & 23.760 & 0.000 & Significant \\
\hline $\begin{array}{l}\text { Tax Avoidance -> Firm } \\
\text { Value }\end{array}$ & 4.399 & 0.011 & Significant \\
\hline \multicolumn{4}{|c|}{ Mediation } \\
\hline Variable & Direct & Indirect & Total effect \\
\hline $\begin{array}{l}\text { Profitability }>\text { tax } \\
\text { avoidance }>\text { firm value }\end{array}$ & -0.263 & -0.012 & -0.275 \\
\hline $\begin{array}{l}\text { Leverage }>\text { tax } \\
\text { avoidance }>\text { firm value }\end{array}$ & 0.164 & -0.002 & 0.162 \\
\hline $\begin{array}{l}\text { Size }>\text { tax avoidance }> \\
\text { firm value }\end{array}$ & -0.275 & 0.014 & -0.262 \\
\hline
\end{tabular}

\subsection{The Effect of Firm Size on Tax Avoidance}

The size of the company or firm size based on analysis and hypothesis testing shows that the size of the company or firm size has no impact on tax avoidance practices. The two variables, namely company size and tax avoidance, have a negative relationship. In the variable of company size, the direction of movement of the minimum variable means that the two variables do not have a positive effect. Results showed that firm size had no effect on tax avoidance. It can be seen that large companies will receive greater attention from tax officials or the tax authorities to 
be taxed in accordance with applicable regulations. This does not apply because paying taxes is an obligation that must be done by the company. Both large and small companies will be monitored and followed up by the tax authorities if they commit tax violations.

\subsection{The Effect of Profitability on Firm Value}

Results of the analysis and hypothesis testing indicate that the profit ratio or profitability has an impact on firm value. If the company's profit has decreased, the company value will increase.

Profit ratio is peroxide by GPM, while firm value is reflected, it can be seen that the GPM value is affected by gross profit. In this study it was found that low profitability does not always have an impact on the value of the company in circulation. The increase in the number of shares outstanding causes investors to feel confident in the company's fundamentals.

\subsection{The Effect of Leverage on Firm Value}

Results of the analysis and hypothesis testing show that the debt ratio or leverage has no impact on firm value. The results showed that the two variables had a relationship that did not have a positive effect because the direction of movement was equally far between the minimum value and the maximum value. The leverage variable only moves in the range of 0.065 , while the highest value in the leverage variable is 39.49 . This also applies to the firm value variable which is 33.57 . Thus, the two variables have no effect in a positive direction.

Leverage is peroxide by the DER indicator, while tax avoidance is peroxide by the CETR. The higher the company's debt, the lower the amount of taxes paid. The high interest cost of debt will cause a reduction in the amount of tax payments by the company. This condition shows that leverage has no effect on tax avoidance.

\subsection{The Effect of Firm Size on Firm Value}

Results of the analysis and testing show that firm size does not have a significant impact on firm value. Its means that the size of the firm value affects the firm value. Firm value is peroxide by PVB. The theory shows that a high sales level reflects the condition of the company in a good condition to earn a profit and has high confidence from investors to make investments. The results of this study are different and not in accordance with the theory. The results of the analysis show that although the size of the company is increasing, it is fundamentally bad for the condition of the company. This can be seen in the downward trend in stock prices.
The fundamental condition of a company is said to be good if its share price increases. Apart from company fundamentals, investors want to invest in companies that have good prospects, regardless of the size of the company. No matter how big a company is, if there are rumors or rumors that the company is experiencing losses and is on the verge of bankruptcy, investors will automatically not invest in the company and this of course has an impact on the decline in the value of the company's shares.

\subsection{The Effect of Tax Avoidance on Company Value}

Results of the analysis and hypothesis testing show that firm value is influenced by tax avoidance. This means that the more tax avoidance increases, the firm value decreases, and vice versa.

The results showed that the tax paid by the company showed a decreasing direction. The decrease in taxes paid was due to the declining net profit of the company. To increase net income, the company increases the number of shares outstanding issued. This in turn has an impact on increasing company value.

\subsection{The Effect of Profitability on Firm Value with Tax Avoidance as an Intervening Variable}

Results of the analysis and hypothesis testing show that tax avoidance is not able to mediate the impact of profitability on firm value. Investors do not only see the size of tax avoidance in investing, but are more focused on the company's performance in earning a profit. If the company experiences an increase in profits, the company's ability to pay dividends also increases. This condition also represents the effect of increasing firm value. In addition, company profits have decreased despite an increase in sales. The decline in profit was due to high costs as a result of the company's high debt ratio. Decreasing company profits will have an impact on small corporate tax payments.

The results showed that firm value increased despite high costs. Decreasing corporate profits have an impact on small corporate tax payments. To improve the company's image as a result of low profitability, the company increases the number of shares outstanding. An increase in the number of shares outstanding will have an impact on increasing company value.

\subsection{The Effect of Leverage on Firm Value with Tax Avoidance as an Intervening Variable}

Results of analysis and hypothesis testing show that tax avoidance cannot mediate the impact of leverage on firm value. In investing, investors do not only look at the 
conditions of tax avoidance practices, but more at the company's ability to manage debt. The leverage of this research is reflected in the Debt to Equity Ratio (DER). It can be seen in the research results that tax avoidance conditions are not able to mediate the effect of leverage on firm value.

The higher amount of funding that comes from debt, the higher the interest costs arising from the debt. High interest costs will have an impact on reducing the company's tax burden. The higher the leverage, the higher the tax avoidance measures. Debt that causes interest expense can be deducted from taxable profit. On the other hand, an increase in debt can be considered as the issuance of the company's ability to provide more returns to investors without having to reduce the proportion of ownership, so that the company's value also increases.

\subsection{The Effect of Firm Size on Firm Value with Tax Avoidance as an Intervening Variable}

Results of the analysis and hypothesis testing show that tax avoidance can mediate the impact of firm size on firm value. Company size is a symbol that can be associated with financial reporting. The condition of the variable size of the company, tax avoidance, and the value of the manufacturing companies in the consumer goods and industry sectors listed on the IDX for the period 20152018 can be seen in the results of the research.

The results show that company size and firm value have increased, while tax avoidance has decreased in the same period, namely 2015-2018. An increase in the level of sales, which is caused by low tax payments, has an impact on increased corporate value. Decreasing tax payments have an impact on increasing share prices.

Large of a company causes the value to increase; this is due to an increase in the number of shares outstanding. To increase company value, one of the things that might be done is to do tax avoidance. Tax avoidance is one of the efforts made by taxpayers to minimize the tax payable in a way that does not conflict with the aims and objectives of the general provisions and provisions of tax laws.

A company with a large size shows the stability and ability of the company to carry out its economic activities. Large companies certainly have human resources who are experts in managing their taxes. Tax avoidance by management is by saving tax burdens so as to increase company profits. The company's increasing profit got a positive reaction from investors. This in turn will have an impact on the company's increased value.

\section{CONCLUSION}

GPM has an effect on tax avoidance; DER has no effect on tax avoidance. Sales have no effect on tax avoidance; GPM has an effect on firm value. DER has no effect on firm value. Sales have an effect on company value. CETR has an effect on firm value. Tax avoidance cannot mediate the impact of leverage on firm value. Tax avoidance can mediate firm size on firm value.

Future research is expected to develop to look for other variables that might influence tax avoidance. Several other factors that may influence tax avoidance are company growth and good corporate governance. In addition, the use of a wider sample, an additional observation period, and a more recent study time are also suggested so that the results of the study are more representative.

\section{REFERENCES}

[1] L. Kaplow. On the undesirability of commodity taxation even when income taxation is not optimal. Journal of Public Economics, 90 (6-7) (2006) 1235-1250. DOI: https://doi.org/10.1016/j.jpubeco.200 5.07 .001

[2] S. O. Rego. Tax-avoidance activities of US multinational corporations. Contemporary Accounting Research, 20 (4) (2003) 805-833. DOI: https://doi.org/1 0.1506/VANN-B7UB-GMFA-9E6W

[3] S. Chen, X. Chen, Q. Cheng, T Shevlin. Are family firms more tax aggressive than non-family firms?. Journal of financial economics, 95 (1) (2010) 41-61. DOI: https://doi.org/10.1016/j.jfineco.2009.02.0 03

[4] S. D. Dyreng, M. Hanlon, E. L. Maydew. The effects of executives on corporate tax avoidance. The accounting review, 85 (4) (2010) 1163-1189. DOI: https://doi.org/10.2308/accr.2010.85.4.1163

[5] M. Hanlon, S. Heitzman. A review of tax research. Journal of accounting and Economics, 50 (23) (2010) 127-178. DOI: https://doi.org/10.1016/j.jacce co.2010.09.002

[6] H. Bringham. Financial Management 8th edition. Jakarta: Erlangga, 2001.

[7] M. Z. Frank, V. K. Goyal. Testing the pecking order theory of capital structure. Journal of financial economics, 67(2) (2003) 217-248. DOI: https://doi.org /10.1016/S0304-405X(02)00252-0

[8] J. Watson. Modeling the relationship between networking and firm performance. Journal of Business Venturing, 22 (6) (2007) 852-874. DOI: https://doi.org/ 10.1016/j.jbusvent.2006.08.001

[9] I. Bernolak. Effective measurement and successful elements of company productivity: The basis of 
competitiveness and world prosperity. International Journal of Production Economics, 52(1-2) (1997) 203213. DOI: https://doi.org/10.1016/S0925-5273(97)00 026-1

[10] R. DeYoung, K. P. Roland. Product mix and earnings volatility at commercial banks: Evidence from a degree of total leverage model. Journal of Financial Intermediation, 10 (1) (2001) 54-84. DOI: https://doi.or g/10.1006/jfin.2000.0305

[11] I. Welch. Two common problems in capital structure research: The financial-debt-to-asset ratio and issuing activity versus leverage changes. International review of finance, 11 (1) (2011) 1-17. DOI: https://doi.org/10.1111/j.1468-2443.2010.01125.x

[12] T. Nguyen, H. Nguyen. Capital structure and firm performance of non-financial listed companies: Crosssector empirical evidences from Vietnam. Accounting, 6 (2) (2020) 137-150. DOI: https://doi.org/10.5267/ j.ac.2019.11.002

[13] H. N. Dang, V. T. T. Vu, X. T. Ngo, H. T. V. Hoang. Study the impact of growth, firm size, capital structure, and profitability on enterprise value: Evidence of enterprises in Vietnam. Journal of Corporate Accounting \& Finance, 30 (1) (2019) 144160. DOI: https://doi.org/10.1002/jcaf.22371

[14] X. Meng, P. Boyd. The role of the project manager in relationship management. International Journal of Project Management, 35 (5) (2017) 717-728. DOI: https ://doi.org/10.1016/j.ijproman.2017.03.001

[15] C. Gao, T. Zuzul, G. Jones, T. Khanna. Overcoming institutional voids: A reputation-based view of long-run survival. Strategic Management Journal, 38 (11) (2017) 2147-2167. DOI: https://doi.org $/ 10.1002 / \mathrm{smj} .2649$

[16] M. A. Rezki, M, N. A. Achsani, H. Sasongko. How Does Tax Avoidance Affect Firm Value?(Lessons From Soe And Indonesian Private Companies). Indone sianJournal Of Business And Entrepreneurship (Ijbe), 6(3) (2020) 215-215. DOI: https://Doi.Org/10.17 358/Ijbe.6.3.215

[17] E. F. Brigham, J. F. Houston. Dasar- Dasar Manajemen Keuangan, Jakarta: Salemba empat, 2010. 